\title{
FENOLOGI PEMBUNGAAN Rhizophora mucronata Lamk. DI HUTAN MANGROVE PASURUAN, JAWA TIMUR
}

\author{
(Flowering Fenology of Rhizophora mucronata Lamk. at Mangrove Forest Pasuruan, \\ East Java)
}

\author{
Liliana Baskorowati $^{1 *}$, Subagya ${ }^{2}$, Mohammad Mahmud ${ }^{3}$ dan/and Mudji Susanto ${ }^{1}$ \\ ${ }^{1}$ Forest Biotechnology and Tree Improvement Research and Development Centre \\ Jl. Palagan Tentara Pelajar Km 15, Purwobinangun, Pakem, Sleman, Yogyakarta, Indonesia \\ ${ }^{2} \mathrm{CV}$ Sumber Rejeki Mangrove Nursery and Plantation \\ Dusun Pesisir, Desa Panunggal, Kecamatan Nguling, Kabupaten Pasuruan, Jawa Timur, Indonesia \\ ${ }^{3}$ Unit Pelaksana Teknis Perbinahan Tanaman Hutan, Dinas Kehutanan Provinsi Jawa Timur \\ Jl Gayungsari Barat No 54-56, Surabaya, Indonesia \\ *E-mail: liliana.baskorowati@gmail.com
}

Tanggal diterima: 3 Oktober 2018; Tanggal direvisi: 10 November 2018;

Tanggal disetujui: 20 November 2018

\begin{abstract}
Rhizophora mucronata Lamk. is a mangrove species developed for rehabilitation program along the north coast of Java Island. Increasing demand of propagules lead to the importance of gaining information regarding the flowers, fruits and propagules production within the area designated as seed source. Therefore, this research aimed to identify the flowers and propagules of $\underline{\mathrm{R}}$. mucronata production in the seed source area of Pesisir, Pasuruan, East Java. Flowering and fruiting phenology were observed by taking samples of trees to identify the development of the flowers and the propagules. Propagule production was observed by making a plot of $5 \times 5 \mathrm{~m}$, with the distance between plots measuring $100 \mathrm{~m}$. Parameters of diameter, total height, and seed production were carried out on all trees in the plot. The results showed that $\underline{\mathrm{R}}$. mucronata bloomed throughout the observation period (January-April), with flowering that was not simultaneously in one tree. Reproductive cycle of this species took 15-16 month from bud commencement to propagule maturations; peak of flowering occurs from March to April and propagule production occurs on August. Propagules reach maturity and are ready for harvesting on December-January.
\end{abstract}

Key words: Mangrove, Rhizophora mucronata, flowering, propagules

\begin{abstract}
ABSTRAK
Rhizophora mucronata Lamk. merupakan jenis tanaman mangrove yang dikembangkan untuk program rehabilitasi areal pantai utara Pulau Jawa. Informasi mengenai produksi propagula $R$. mucronata menjadi penting agar kebutuhan buah tercukupi. Penelitian ini ditujukan untuk mengetahui fenologi pembungaan dan pembuahan $R$. mucronata di areal sumber benih teridentifikasi Dusun Pesisir, Pasuruan, Jawa Timur. Fenologi pembungaan, pembuahan, dan produksi propagula diamati pada tiga sampel pohon per petak ukur. Produksi propagula diamati dengan membuat petak ukur 5 x 5 m, dengan jarak antar petak ukur 100 m; yang dibedakan antara petak ukur di tepi pantai dan di tepi daratan. Total petak ukur yang diamati ada sebanyak sepuluh petak ukur. Pengambilan data diameter, tinggi total dan produksi propagula dilakukan untuk semua pohon dalam petak ukur. Hasil penelitian menunjukkan bahwa $R$. mucronata berbunga selama pengamatan (Januari-April), dengan pembungaan yang tidak serempak dalam satu pohon. Siklus reproduksi memerlukan waktu 15-16 bulan mulai dari terbentuknya tunas sampai masaknya propagula; dengan puncak pembungaan terjadi pada bulan Maret-April dan musim berbuah pada bulan Agustus. Propagula mencapai tingkat masak siap dipanen pada bulan Desember-Januari.
\end{abstract}

Kata kunci : Mangrove, Rhizophora mucronata, pembungaan, propagula 


\section{PENDAHULUAN}

Luas ekosistem hutan mangrove di Indonesia mencapai sekitar 3,5 juta ha, yang tersebar di 257 kabupaten dan kota di Indonesia; dengan kondisi mangrove yang telah mengalami kerusakan seluas 1,085 juta ha (Times-Indonesia, 2017). Kerusakan hutan mangrove tersebut sebanyak 85\% terjadi di Pantai Utara Jawa (Pantura), dengan laju kerusakan hutan mangrove 50.000 ha/tahun karena konversi lahan (Berita Trans, 2017). Ditjen Rehabilitasi dan Reboisasi Lahan menyatakan sebanyak 1,6 juta ha $(43,2 \%)$ luas mangrove dalam kawasan hutan dalam kondisi rusak dan 4,8 juta ha $(87,3 \%)$ di luar kawasan dalam keadaan rusak parah (Onrizal, 2010). Pemerintah Indonesia melalui Kementerian Kelautan dan Perikanan (KKP) dan Kementerian Lingkungan Hidup dan Kehutanan (KLHK) secara berkelanjutan menggalakkan kegiatan rehabilitasi lahan mangrove untuk ditanami pohon dari famili Rhizophoraceae. Kegiatan rehabilitasi bertujuan untuk memulihkan fungsi utama hutan mangrove untuk menahan laju erosi pantai, menyerap energi badai laut, menjaga sedimen pantai, serta melindungi terumbu karang (Dale, Knight, \& Dwyer, 2014). Di Indonesia terdapat beberapa jenis pohon mangrove, namun jenis Rhizophora mucronata Lamk. menjadi pilihan para petani mangrove untuk dikembangkan karena kemudahannya untuk tumbuh. Rhizophora merupakan jenis bakau yang sangat penting dari seluruh genera di daerah tropik maupun subtropik (Sharma, Analuddin, \& Hagihara, 2010). Jenis ini juga memiliki nilai ekonomi yang tinggi karena kayunya dapat dipergunakan sebagai kayu konstruksi dan arang (Salina, 2009; Onrizal, 2010).

Permintaan bibit Rhizophora terus meningkat untuk memenuhi kegiatan reboisasi; namun belum dapat terpenuhi karena kurangnya koleksi propagula saat musim berbuah. Pengetahuan tentang reproduksi biologi khususnya fenologi pembungaan dan tingkat keberhasilan produksi propagula sangat diperlukan, karena dengan adanya informasi kapan terjadinya pembungaan dan pembuahan akan mempermudah petani untuk mengetahui pasokan benih yang dapat disediakan musim panen selanjutnya. Studi fenologi menjadi penting karena dapat digunakan untuk memprediksi kemampuan pohon dalam produksi benih atau propagula serta untuk menentukan strategi pengembangan jenis tersebut (Baskorowati, Moncur, Doran, \& Kanowski, 2010; Nordatul Akmar \& Wan Juliana, 2012). Keberhasilan reproduksi dapat diketahui dengan mengetahui proses fenologi tanaman sepertu waktu, durasi, dan intensitas pembungaan serta pembuahan (Baskorowati, 2013). Kegiatan penanaman kembali hutan mangrove akan berkelanjutan dengan diketahuinya informasi tentang puncak pembungaan dan pembuahan, sehingga pengumpulan propagula dapat tepat waktu. Dengan demikian, studi untuk mengetahui waktu dan perkembangan bunga dan propagula; serta mengetahui produksi propagula dari $\underline{\mathrm{R}}$. mucronata menjadi penting untuk diteliti.

\section{METODOLOGI}

\section{A. Waktu dan Tempat Penelitian}

Pengambilan data dilakukan di hutan mangrove Dusun Pesisir, Desa Panunggal, Kecamatan Nguling, Kabupaten Pasuruan, Jawa Timur. Secara geografis hutan mangrove tersebut terletak pada 07\%42'206" LS dan $113^{\circ} 05^{\prime} 622^{\prime \prime}$ BT. Pengamatan dimulai pada bulan September 2016 sampai dengan bulan Maret 2018.

\section{B. Metode}

\section{Pengamatan fenologi pembungaan dan pembuahan}

Fenologi pembungaan dan pembuahan diamati secara langsung dengan 
observasi per pohon contoh (Nordatul Akmar \& Wan Juliana, 2012). Pengamatan dilakukan dari mulai munculnya tunas calon bunga sampai kematangan propagula. Jumlah pohon yang diamati sebanyak tiga pohon per petak ukur, total petak ukur yang diamati sebanyak sepuluh petak.

Pengamatan kuantitatitaf dilakukan dengan mengukur dimensi karakteristik bunga terhadap parameter yang ditetapkan (Tabel 1). Pengukuran dimensi karakteristik bunga dilakukan dengan cara mengambil sampel bunga pada tahap sebelum mekar dan bunga yang sudah mekar masing-masing sepuluh bunga. Pengukuran karakteristik bunga dilakukan dengan menghitung masing-masing karakter bunga maupun pengukuran menggunakan penggaris. Pengamatan kualitatif perkembangan tunas bunga, pembungaan, dan pembuahan dilakukan pada bulan September ketika tunas pembungaan mulai muncul dan diamati proses perkembangannya secara periodik 1 bulan sekali. Pembungaan diamati pada bulan Februari sampai dengan April dilakukan setiap minggu; selanjutnya pengamatan dilakukan setiap bulan sampai propagula masak.

\section{Pengamatan intensitas produksi propagula}

Pengamatan intensitas produksi propagula diamati pada beberapa pohon contoh dengan menggunakan metode pembuatan petak ukur permanen ukuran 5 x $5 \mathrm{~m}$; dengan jarak antar petak ukur 100 $\mathrm{m}$; yang dibedakan antara petak ukur di tepi pantai (diujung pantai, sehingga lebih terendam air laut dan terpapar angin laut) dan di tepi daratan (dekat dengan daratan). Parameter diameter batang, tinggi total, dan produksi benih diamati pada semua pohon dalam petak ukur. Diameter batang diukur setinggi dada dengan menggunakan pita diameter (phi band), sedangkan tinggi diukur dengan menggunakan galah ukur. Produksi propagula dilakukan dengan memberikan skor dengan kriteria sebagai berikut; skor 1 = tidak berbuah sama sekali; 2 = berbuah sedikit; 3 = berbuah sedang; dan skor $4=$ berbuah banyak. Dari masing-masing skor diambil sepuluh pohon yang dihitung jumlah propagulanya sehingga didapatkan rerata jumlah propagula per skor.

\section{Analisis data}

Data pengamatan dianalisis menggunakan analisis varians dilakukan untuk melihat hubungan antara (1) parameter yang diukur dengan posisi petak ukur digunakan model linier sebagai berikut: $\mathrm{Y}$ $=\mu($ rerata umum $)+$ posisi petak ukur + error; (2) parameter dimensi karakteristik bunga digunakan model linier sebagai berikut: $\mathrm{Y}=\mu$ (rerata umum) + karakteristik bunga + error.

\section{HASIL DAN PEMBAHASAN}

A. Hasil

1. Fenologi pembungaan dan pem-
buahan

Dari pengamatan fenologi pembungaan menunjukkan bahwa bunga $\mathrm{R}$. mucronata bersifat biseksual atau berumah dua, dimana dalam satu bunga terdapat organ betina (kepala putik) dan organ pejantan (benang sari). Struktur bunga R. mucronata (Gambar 1) terdiri dari kelopak bunga (calyx) yang berjumlah 4 berwarna kuning muda atau hijau kekuningan; mempunyai mahkota bunga (corolla) berjumlah 4 berwarna putih dan berbulu tebal di seluruh pinggirannya; benang sari (stamen) berjumlah 8 dan putik (style). Infloresens berkarang, terdiri dari 4-8 kuncup bunga dalam setiap karang dengan pembungaan yang tidak serempak. Dimensi karakteristik bunga disajikan dalam Tabel 1 . 
Tabel (Table) 1. Dimensi karakteristik bunga R. mucronata (The dimension of key floral characteristics of $\underline{\mathrm{R}}$. mucronata)

\begin{tabular}{lccc}
\hline $\begin{array}{c}\text { Karakteristik yang diukur } \\
\text { (Floral characteristic measurement) }\end{array}$ & $\begin{array}{c}\text { Unit } \\
\text { (Unit) }\end{array}$ & $\begin{array}{c}\text { Rerata } \\
\text { (Mean) }\end{array}$ & $\begin{array}{c}\text { Standar error } \\
\text { (Standard } \\
\text { error) }\end{array}$ \\
\hline $\begin{array}{l}\text { 1. Panjang kuncup (sebelum mekar) } \\
\text { (Length of bud) (before anthesis) }\end{array}$ & $\mathrm{Cm}$ & 1.34 & 0.13 \\
2. Diameter kuncup (Diameter of bud) & $\mathrm{Mm}$ & 0.51 & 0.08 \\
3. Jumlah kelopak bunga (Number of calyx) & Buah (Number) & 4.00 & 0.00 \\
4. Panjang mahkota bunga (Length of & $\mathrm{Cm}$ & 1.43 & 0.08 \\
$\begin{array}{l}\text { corolla) } \\
\text { 5. Jumlah anther dalam 1 bunga (Number } \\
\text { of anther in 1 flower) }\end{array}$ & Buah (Number) & 8.00 & 0.00 \\
6. Panjang kelopak bunga (Length of calyx) & $\mathrm{Cm}$ & 1.08 & 0.10 \\
7. Panjang anther (Length of anther) & $\mathrm{Cm}$ & 0.58 & 0.03 \\
\hline
\end{tabular}

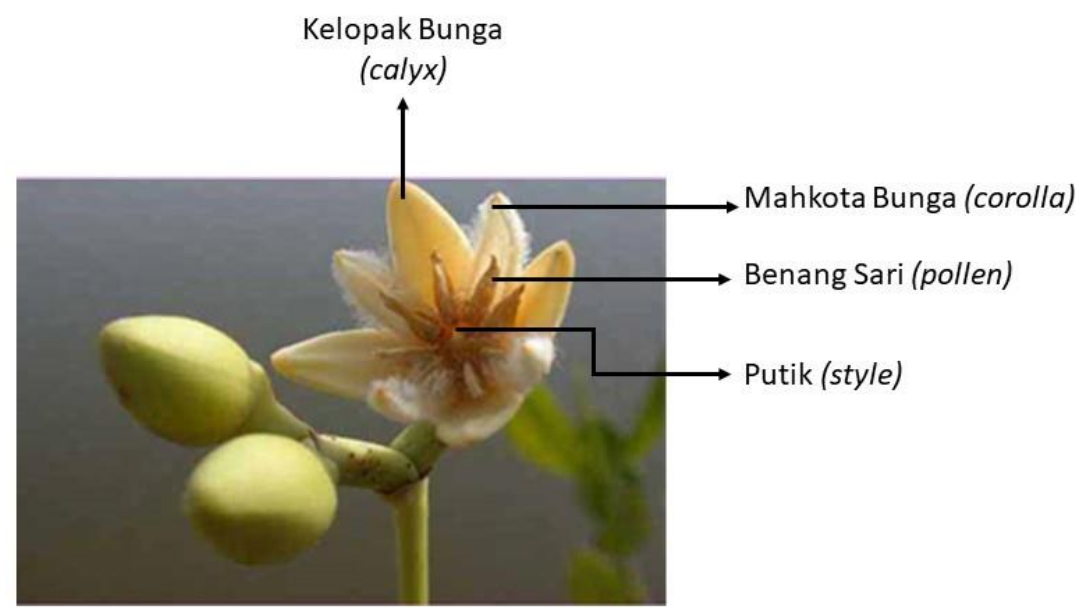

Gambar (Figure) 1. Struktur bunga R. mucronata (Floral structure of $\underline{\text { R. mucronata) }}$ (www.prota4u.org)

Diantara individu-individu bunga yang diobservasi, tidak ada perbedaan yang nyata $(\mathrm{P}<0,0001)$ dalam hal panjang kuncup (sebelum mekar), diameter kuncup, jumlah mahkota bunga, jumlah antera dalam satu bunga, panjang mahkota bunga, dan panjang antera. Proses perkembangan organ generatif jenis $R$. mucronata di lokasi penelitian terjadi sepanjang tahun, dengan puncak pembungaan yang terjadi bulan Maret sampai dengan April dan puncak produksi propagula bulan Agustus sampai dengan Desember. Hasil pengamatan perkembangan organ generatif pada R. mucronata dijabarkan pada Tabel 2 .

\section{Intensitas produksi}

Hasil pengukuran pertumbuhan tanaman serta produksi propagula disajikan pada Tabel 3. Hasil analisis varians menunjukkan bahwa posisi petak ukur berpengaruh nyata terhadap produksi propagula $(\mathrm{P}=0,02)$ dan berpengaruh sangat nyata terhadap pertumbuhan diameter $(\mathrm{P}=0.0001)$. Posisi petak ukur juga berpengaruh sangat nyata terhadap pertumbuhan tinggi tanaman $(\mathrm{P}=0.0001)$. Analisis varians juga menunjukkan bahwa perbedaan kelas diameter tidak dipengaruhi oleh posisi petak ukur. 
Tabel (Table) 2. Tahapan perkembangan bunga, dan buah R. mucronata di hutan mangrove Pesisir, Pasuruan, Jawa Timur (Stages of floral and fruit development of $\underline{\mathrm{R}}$. mucronata at Mangrove Forest Pesisir, Pasuruan, Jawa Timur)

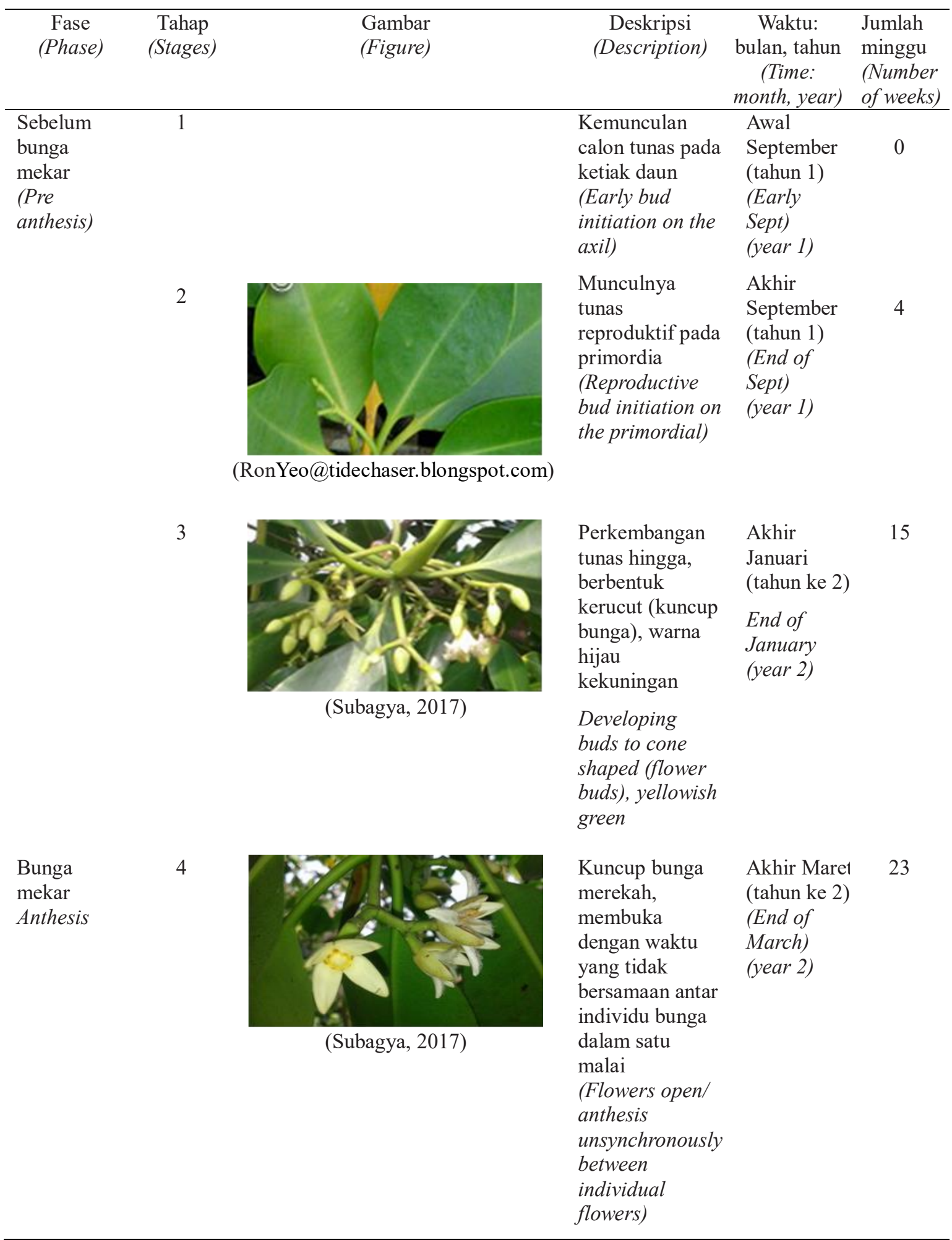


Jurnal Penelitian Hutan Tanaman

Vol. 15 No. 2, Desember 2018, 113-123

Tabel (Table) 2. Lanjutan (Continued)

\begin{tabular}{|c|c|c|c|c|c|}
\hline $\begin{array}{c}\text { Fase } \\
\text { (Phase) }\end{array}$ & $\begin{array}{c}\text { Tahap } \\
\text { (Stages) }\end{array}$ & $\begin{array}{l}\text { Gambar } \\
\text { (Figure) }\end{array}$ & $\begin{array}{c}\text { Deskripsi } \\
\text { (Description) }\end{array}$ & $\begin{array}{c}\text { Waktu: } \\
\text { bulan, tahun } \\
\text { (Time: } \\
\text { month, year) }\end{array}$ & $\begin{array}{l}\text { Jumlah } \\
\text { minggu } \\
\text { (Number } \\
\text { of weeks) }\end{array}$ \\
\hline & 5 & agya, 20 & $\begin{array}{l}\text { Bunga } \\
\text { berkembang } \\
\text { dengan } \\
\text { mahkota bunga } \\
\text { dan athers layu } \\
\text { setelah } \\
\text { pembuahan } \\
\text { (Developing } \\
\text { flowers with } \\
\text { withered } \\
\text { corolla and } \\
\text { anthers after } \\
\text { fertilization) }\end{array}$ & $\begin{array}{l}\begin{array}{l}\text { Awal April } \\
\text { (tahun ke 2) }\end{array} \\
\text { (Early } \\
\text { April) }\left(2^{\text {nd }}\right. \\
\text { year) }\end{array}$ & $24-25$ \\
\hline $\begin{array}{l}\text { Perkembangan } \\
\text { buah } \\
\text { (Fruit } \\
\text { development) }\end{array}$ & 6 & gya & $\begin{array}{l}\text { Perkembangan } \\
\text { ukuran buah } \\
\text { yang berwarna } \\
\text { coklat; } \\
\text { sedangkan } \\
\text { kelopak bunga } \\
\text { berubah warna } \\
\text { menjadi hijau } \\
\text { (Developing of } \\
\text { young fruit } \\
\text { with brown } \\
\text { color; while } \\
\text { the petals turn } \\
\text { green) }\end{array}$ & $\begin{array}{l}\text { Awal Juni } \\
\text { (tahun ke-2) } \\
\text { Early June } \\
\text { (2 } 2^{\text {nd }} \text { year) }\end{array}$ & 32 \\
\hline & 7 & bagya, 20 & $\begin{array}{l}\text { Perkembangn } \\
\text { buah pada } \\
\text { ukuran } \\
\text { maksimal, } \\
\text { hipokotil } \\
\text { muncul } \\
\text { (Developing } \\
\text { fruit at } \\
\text { maximum size } \\
\text { with the } \\
\text { emergence of } \\
\text { hypocotyl) }\end{array}$ & $\begin{array}{l}\text { Awal } \\
\text { September } \\
\text { (tahun ke-2) } \\
\text { (Early } \\
\text { September) } \\
\text { (2nd year) }\end{array}$ & 44 \\
\hline
\end{tabular}


Fenologi Pembungaan Rhizophora mucronata Lamk. di Hutan Mangrove Pasuruan, Jawa Timur

Liliana Baskorowati, Subagya, Mohammad Mahmud dan Mudji Susanto

Tabel (Table) 2. Lanjutan (Continued)

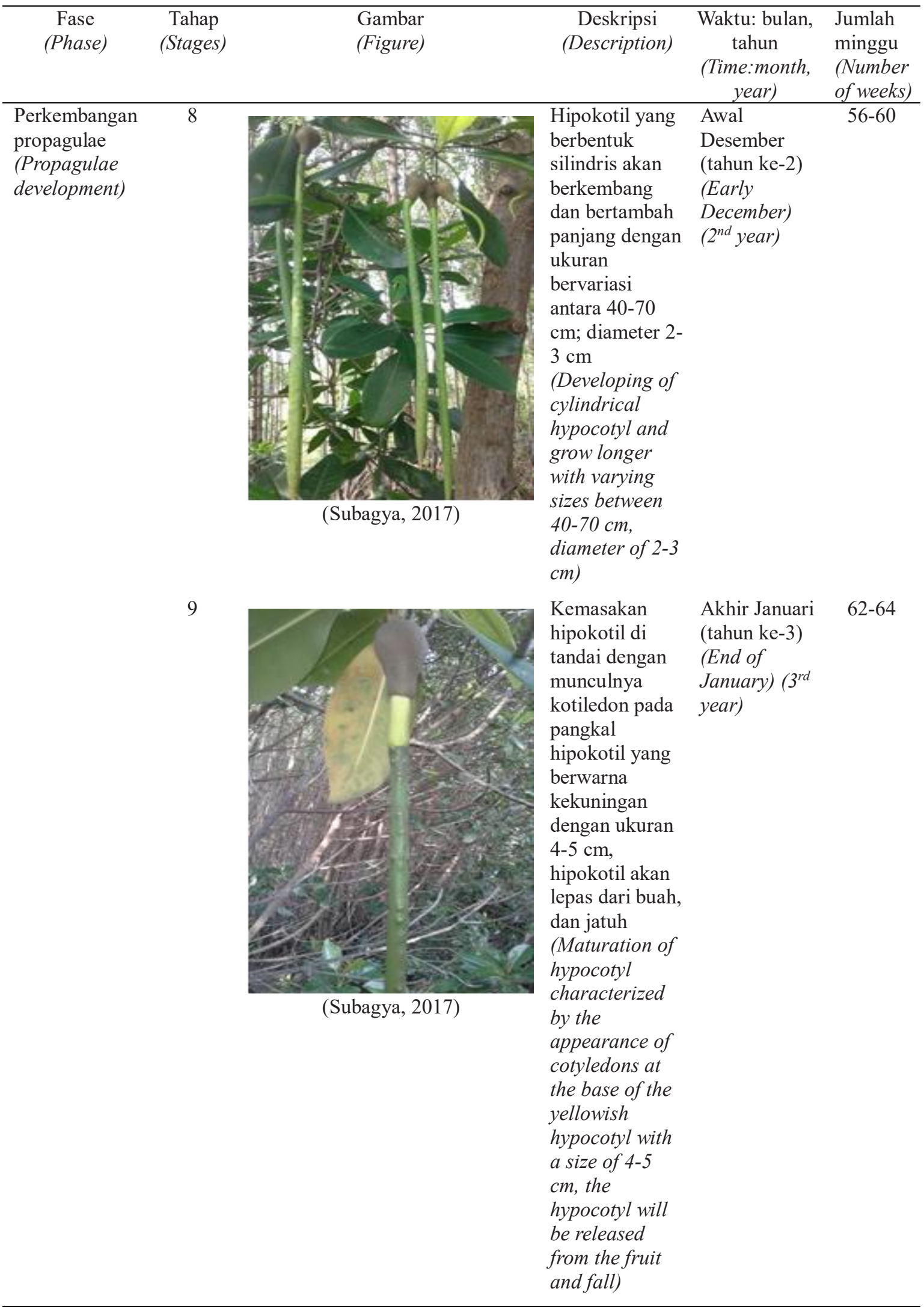


Tabel (Table) 3. Rerata dan standar error diameter batang, tinggi dan produksi propagula $\mathrm{R}$ mucronata (mean and standard error of stem diameter, height, and propagule productions of $\underline{\mathrm{R}} \underline{\text { mucronata) }}$

\begin{tabular}{cccc}
\hline $\begin{array}{c}\text { No } \\
\text { PU }\end{array}$ & $\begin{array}{c}\text { Rerata diameter }(\mathrm{cm}) \\
\text { (Mean of diameter) } \\
(\mathrm{cm})\end{array}$ & $\begin{array}{c}\text { Rerata tinggi }(\mathrm{m}) \\
(\text { Mean of height) } \\
(\mathrm{m})\end{array}$ & $\begin{array}{c}\text { Produksi propagula (skor) } \\
\text { (Propagule production) } \\
\text { (score) }\end{array}$ \\
\hline 1 & $10.33 \pm 4.22$ & $6.67 \pm 0,56$ & $2.00 \pm 0.71$ \\
2 & $8.75 \pm 1.58$ & $7.37 \pm 0,52$ & $1.75 \pm 0.71$ \\
3 & $10.00 \pm 1.33$ & $7.00 \pm 0.00$ & $2.10 \pm 0.88$ \\
4 & $10.38 \pm 1.60$ & $7.75 \pm 0,50$ & $1.88 \pm 0.99$ \\
5 & $12.11 \pm 1.62$ & $10.50 \pm 0,55$ & $2.44 \pm 0.53$ \\
6 & $10.36 \pm 2.38$ & $8.50 \pm 0,93$ & $1.91 \pm 1.04$ \\
7 & $10.38 \pm 2.38$ & $10.50 \pm 0,55$ & $2.13 \pm 0.83$ \\
8 & $12.14 \pm 2.54$ & $10.00 \pm 0,82$ & $2.43 \pm 0.79$ \\
9 & $9.43 \pm 1.40$ & $10.75 \pm 0,71$ & $2.00 \pm 0.68$ \\
10 & $11.30 \pm 2.00$ & $10.50 \pm 0,53$ & 2.500 .53 \\
\hline
\end{tabular}

\section{B. Pembahasan}

Secara umum, faktor genetik dan lingkungan diyakini sebagai faktor yang mempengaruhi fenologi pembungaan. Waktu pembungaan dan pembuahan yang tidak serempak di beberapa kawasan hutan mangrove disajikan pada Tabel 4. Perbedaan lingkungan seperti perbedaan jenis tanah dan letak geografis mempengaruhi terjadinya perbedaan waktu berbunga suatu jenis tanaman antar populasi (Liliana Baskorowati, 2013; Cortés - Flores, Hernández - Esquivel, González - Rodríguez, \& Ibarra Manríquez, 2017).

Perkembangan organ generatif merupakan serangkaian tahapan yang dimulai dari inisiasi bunga; perkembangan bunga menuju reseptif; penyerbukan dan pembuahan; perkembangan buah menuju kemasakan serta masaknya buah (Hartmann, Kester, Davies, \& Geneve, 2010). Seperti yang disampaikan pada Tabel 2, bahwa fase reproduksi pada $\mathrm{R}$. mucronata terbagi dalam 4 fase yaitu preanthesis dimana tunas reproduksi sudah mulai muncul sampai perkembangan kuncup bunga sebelum anthesis (membuka), fase ini membutuhkan waktu yang lama yaitu selama 15 minggu (4 bulan); anthesis atau membukanya kuncup bunga, masaknya organ reproduksi bunga (polen dan putik) sampai luruhnya organ re-produksi bunga, fase ini hanya membutuhkan waktu 1-2 minggu. Dalam proses penyerbukan dan pembuahan; untuk fase post anthesis terbagi lagi menjadi perkembangan buah dan perkembangan propagula yang membutuhkan waktu 8-9 bulan sampai propagula masak dan siap tanam.

Secara keseluruhan, siklus reproduksi R. mucronata di hutan mangrove Desa Pesisir, Pasuruan, Jawa Timur memerlukan waktu 15-16 bulan mulai dari terbentuknya tunas sampai masaknya propagula; dengan puncak pembungaan terjadi pada bulan Maret-April dan musim berbuah pada bulan Agustus. Beberapa penelitian menyebutkan kisaran waktu siklus reproduksi R. mucronata yaitu 1620 bulan (Kamal, 2011; Wang'ondu et al., 2013; 2014). Dalam penelitian ini waktu yang diperlukan oleh R. mucronata mulai dari terbentuknya propagula sampai masak (muncul kotiledon) membutuhkan waktu 8-9 bulan, hampir sama dengan hasil penelitian yang dilaporkan sebelumnya yaitu 6-8 bulan dan 9 bulan (Wang'ondu et al., 2013). 
Tabel (Table) 4. Waktu berbunga dan berbuah R. mucronata di beberapa kawasan hutan mangrove (Time of flowering and fruiting of $\underline{\mathrm{R}}$. mucronata at several mangrove forests)

\begin{tabular}{llll}
\hline \multicolumn{1}{c}{$\begin{array}{c}\text { Lokasi } \\
\text { (Location) }\end{array}$} & $\begin{array}{l}\text { Waktu berbunga } \\
\text { (Flowering time) }\end{array}$ & $\begin{array}{l}\text { Waktu berbuah } \\
\text { (Fruiting time) }\end{array}$ & \multicolumn{1}{c}{$\begin{array}{c}\text { Sumber pustaka } \\
\text { (Reference) }\end{array}$} \\
\hline $\begin{array}{l}\text { Pulau Unggas, } \\
\text { Sumatra Barat } \\
\text { Gazi Bay, Kenya }\end{array}$ & November-Maret & $\begin{array}{l}\text { Agustus- } \\
\text { Desember }\end{array}$ & Kamal (2011) \\
& $\begin{array}{l}\text { Oktober- } \\
\text { September }\end{array}$ & & $\begin{array}{l}\text { Wang'ondu et al. (2013, } \\
\text { 2014). }\end{array}$ \\
$\begin{array}{l}\text { Sungai Pulai, } \\
\text { Malaysia }\end{array}$ & Januari-April, & Maret-Mei & $\begin{array}{l}\text { Nordatul Akmar \& Wan } \\
\text { Juliana (2012) }\end{array}$ \\
$\begin{array}{l}\text { Tanjung Tuan, } \\
\text { Malaysia }\end{array}$ & April-Juni & & $\begin{array}{l}\text { Nordatul Akmar \& Wan } \\
\text { Juliana, (2012); Wan }\end{array}$ \\
& & & $\begin{array}{l}\text { Juliana, Farihah, Nordatul } \\
\text { Akmar, Muhamad Rizali, }\end{array}$ \\
& & & \& Nurhanim (2011). \\
\hline
\end{tabular}

Baik faktor genetik maupun lingkungan diketahui sebagai penyebab adanya perbedaan fenologi pembungaan antar spesies, contohnya periode waktu pembungaan yang berbeda dalam satu jenis tanaman dapat dipengaruhi oleh kondisi lingkungan terjadinya pembungaan (Baskorowati et al., 2010; Baskorowati, 2013). Penelitian fenologi R. mucronata oleh Wang'ondu et al. (2013; 2014) menunjukkan bahwa kemunculan struktur reproduksi jenis ini dipengaruhi oleh iklim; dimana pembentukan kuncup bunga berkorelasi dengan kelembapan dan suhu udara; pembungaan berhubungan dengan curah hujan, dan perkembangan propagula dipengaruhi oleh curah hujan, suhu, dan kelembapan. Terdapat hubungan yang kuat antara proses reproduksi tanaman mangrove dengan curah hujan; dimana panjangnya sinar matahari, curah hujan, dan suhu ditengarai sangat mempengaruhi terjadinya pembungaan dan pembuahan pada jenis mangrove (Nadia, Morellato, \& Machado, 2012; Wang'ondu et al., 2013).

Hasil analisis varians menunjukkan bahwa posisi petak ukur berpengaruh nyata terhadap produksi propagula $(\mathrm{P}=$
$0,02)$ dengan rerata produksi propagula lebih banyak pada tanaman yang berada di dekat daratan dibandingkan dengan tanaman yang di dekat pantai. Hal tersebut diduga karena faktor terpaan angin laut yang menyebabkan jumlah pollinator yang membantu penyerbukan menjadi berkurang. Seperti diketahui bahwa angin dan serangga memegang peranan yang penting terhadap proses penyerbukan jenis ini.

Penelitian sebelumnya menyatakan bahwa angin dan serangga menjadi pollinator pada R. mucronata ( Willmer, 2012; Wang'ondu et al., 2013). Penelitian lain menyebutkan bahwa serangga (lebah madu, semut dan ngengat) lebih memungkinkan menjadi faktor utama penyerbukan dibandingkan angin (Pandey, Pandey, \& Jain, 2010). Dalam penelitian ini, diasumsikan bahwa yang menjadi agen utama proses penyerbukan adalah serangga, sehingga dengan kuatnya terpaan angin akan menyebabkan jumlah kunjungan serangga menjadi berkurang; yang akhirnya berpengaruh pada keberhasilan reproduksi pohon-pohon yang di dekat pantai menjadi lebih sedikit dibandingkan yang di tepi dataran. Angin 
yang kencang juga menyebabkan gugurnya bunga yang sedang mekar, sehingga akan mempengaruhi jumlah keberhasilan buah/propagula. Pembungaan berjalan tidak serempak, sehingga propagula yang sudah masak juga dijumpai pada saat puncak pembungaan meskipun dalam jumlah yang sedikit.

\section{KESIMPULAN DAN SARAN}

\section{A. Kesimpulan}

Produksi propagula R. mucronata di hutan mangrove Dusun Pesisir, Pasuruan dipengaruhi oleh keberhasilan penyerbukan, yang dipengaruhi oleh letak tanaman. Produksi propagula R. mucronata dipengaruhi oleh posisi tanaman dalam hutan mangrove tersebut. Semakin dekat posisi tanaman dengan laut; produksi propagula semakin sedikit. Proses pembungaan dan pembuahan $\mathrm{R}$. mucronata di hutan mangrove Dusun Pesisir membutuhkan waktu 15-16 bulan. Siklus reproduksi R. mucronata terbagi dalam empat tahap, yaitu tahap preanthesis atau perkembangan kuncup bunga; anthesis atau membukanya bunga dan berfungsinya organ-organ reproduksi baik kepala sari maupun serbuk sari sampai terjadinya proses pembuahan; post-anthesis perkembangan bakal buah; dan post-antheis perkembangan propagula sampai siap tanam. R. mucronata mulai berbunga pada bulan Maret-April, musim berbuah Agustus-September. Waktu yang diperlukan untuk kemasakan propagula adalah 8-9 bulan, sehingga propagula akan siap untuk dipanen pada bulan DesemberJanuari.

\section{B. Saran}

Pengunduhan propagula R. mucronata di hutan mangrove Dusun Pesisir, Pasuruan, Jawa Timur disarankan dilakukan pada bulan Desember sampai dengan Januari. Meskipun dalam jumlah sedikit dapat ditemui juga propagula yang masak pada bulan September-Desember.

\section{UCAPAN TERIMA KASIH}

Penulis mengucapkan banyak terima kasih kepada CV. Sumber Rejeki Mangrove Nursery and Plantation, Dusun Pesisir, Desa Panunggal, Kecamatan Nguling, Kabupaten Pasuruan, Jawa Timur, Indonesia atas bantuannya selama pengambilan data di lapangan. Tidak lupa penulis mengucapkan banyak terima kasih kepada seluruh jajaran Unit Pelaksana Teknis Perbenihan Tanaman Hutan, Dinas Kehutanan Provinsi Jawa Timur, atas kesempatan yang diberikan kepada penulis untuk melakukan kajian ini.

\section{DAFTAR PUSTAKA}

Baskorowati, L. (2013). Pengaruh faktor lingkungan terhadap intensitas pembungaan Melaleuca alternifolia. Jurnal Pemuliaan Tanaman Hutan, 7(1), 15-28.

Baskorowati, L., Moncur, M.W., Doran, J.C., \& Kanowski, P.J. (2010). Reproductive biology of Melaleuca alternifolia (Myrtaceae) 1. Floral biology. Australian Journal of Botany, 58(5), 373-383. https://doi.org/10.1071/BT10035.

Berita Trans. (2017). Rehabilitasi hutan mangrove tak bisa lagi andalkan KKP dan KLHK. Berita Trans.Com. Retrieved from https://aksi.id/artikel/18541/

Rehabilitasi-Hutan-Mangrove-TakBisa-Lagi-Andalkan-KKP-danKLHK/

Cortés-Flores, J., Hernández-Esquivel, K., González-Rodríguez, A., \& IbarraManríquez, G. (2017). Flowering phenology, growth forms, and pollination syndromes in tropical dry forest species: Influence of phylogeny and abiotic factors. American Journal of Botany. https://doi.org/10.3732/ajb.1600305.

Dale, P.E.R., Knight, J.M., \& Dwyer, P.G. (2014). Mangrove rehabilitation: a 
review focusing on ecological and institutional issues. Wetlands Ecology and Management. https://doi.org/10.1007/s11273-0149383-1.

Hartmann, H., Kester, D., Davies, F., \& Geneve, $\quad R$. (2010). Plant propagation: principles and practices. Biochemical Systematics and Ecology. https://doi.org/10.1016/03051978(90)90018-B.

Kamal, E. (2011). Fenologi mangrove ( Rhizophora apiculata, R. mucronata dan R . stylosa) di Pulau Unggas, Air Bangis Pasaman Barat, Sumatera Barat. Jurnal Natur Indonesia, 14(1), 90-94.

Nadia, T. de L., Morellato, L.P.C., \& Machado, I.C. (2012). Reproductive phenology of a northeast Brazilian mangrove community: environmental and biotic constraints. Flora: morphology, distribution, functional ecology of plants. https://doi.org/10.1016/j.flora.2012. 06.020 .

Nordatul Akmar, Z., \& Wan Juliana, W.A. (2012). Reproductive phenology of two rhizophora species in Sungai Pulai Forest Reserve, Johor, Malaysia. Malaysian Applied Biology, 41(1), 11-21.

Onrizal. (2010). Perubahan tutupan hutan mangrove di Pantai Timur Sumatera Utara periode 1977-2006. Jurnal Biologi Indonesia, 6(2), 163-172.

Pandey, C.N., Pandey, R., \& Jain, B.K. (2010). Reproductive phenology of Rhizophora mucronata Lamk. (rhizophoraceae) in the gulf of Kachchh, Gujarat, India. Phytomorphology: An International Journal of Plant Morphology, 60(34), 91-100.

Salina, K. (2009). Saving the mangroves: nursery created to keep costs down. Starmetro.

Sharma, S., Analuddin, K., \& Hagihara, A.
(2010). Phenology and litterfall production of mangrove Rhizophora stylosa Griff . in the subtropical region, Okinawa Island, Japan. Proc. of International Conference on Environmental Aspects of Bangladesh (ICEAB10), Japan, Sept. 2010.

Times-Indonesia. (2017). Luas lahan mangrove di Indonesia semakin merosot. Times Indonesia. Retrieved from https://www.timesindonesia.co. $\mathrm{id} / \mathrm{read} / 146434 / 20170418 / 180940 /$ luas-lahan-mangrove-di-indonesiasemakin-merosot/

Wan Juliana, W., Farihah, A., Nordatul Akmar, Z., Muhamad Rizali, S., \& Nurhanim, M. (2011). Phenology of rhizophora species at three peninsular Malaysia mangrove forests. In Proceeding of Universiti Malaysia Terengganu 10th Annual Symposium (UMTAS 2011). Kuala Terengganu, 11-13 Juli (pp. 12-17).

Wang'ondu, V.W., Bosire, J.O., Kairo, J.G., Kinyamario, J.I., Mwaura, F. B., Dahdouh-Guebas, F., \& Koedam, N. (2014). Litter fall dynamics of restored mangroves (Rhizophora mucronata Lamk. and Sonneratia alba Sm.) in Kenya. Restoration Ecology.

https://doi.org/10.1111/rec.12149.

Wang'ondu, V.W., Kairo, J.G., Kinyamario, J.I., Mwaura, F.B., Bosire, J.O., Dahdouh-Guebas, F., \& Koedam, N. (2013). Vegetative and reproductive phenological traits of Rhizophora mucronata Lamk. and Sonneratia alba Sm. Flora Morphology, Distribution, Functional Ecology of Plants, 208(8), 522-531. https://doi.org/ 10.1016/j.flora.2013.08.004.

Willmer, P.G. (2012). Ecology. Pollinatorplant syncrony tested by climate change. Current Biology, 22, 131132. 